\title{
IMPLEMENTATION OF SOFT SKILLS ON AUTOMOTIVE ENGINEERING PRACTICUM OF STATE VOCATIONAL HIGH SCHOOLS IN WEST LOMBOK REGENCY
}

\author{
Aprian Firmansyah $^{1 *}$, Soeharto ${ }^{1}$ \\ ${ }^{1}$ Universitas Negeri Yogyakarta
}

Jl. Colombo No. 1, Karangmalang, Depok, Sleman, Yogyakarta 55281, Indonesia

\begin{abstract}
This research aims to reveal the implementation of soft skills in the expertise program of automotive workshop at vocational high schools (VHS) in West Lombok Regency in terms of (1) student condition and practicum lesson planning, and (2) level of soft skills in automotive technology practicum of VHS students. This research is quantitative research with a descriptive approach. The research population is all state vocational high schools (SVHS) of light vehicle technology in West Lombok. The sample is four vocational high schools with 84 grade XII students and four teachers established using the purposive sampling technique. The research finding shows that (1) the student condition in the implementation of soft skills is in a good category with the achievement percentage of $46.43 \%$ and the lesson plan condition is in a good category with the achievement percentage of $58.33 \%$; (2) the achievement level of soft skill is in a good category with the achievement percentage of $49 \%$.
\end{abstract}

Keywords: implementation, soft skills, vocational high school

How to cite: Firmansyah, A., \& Soeharto, S. (2020). Implementation of soft skills on Automotive Engineering practicum of state vocational high schools in West Lombok $\begin{array}{llll}\text { Regency. Jurnal Pendidikan } & \text { Vokasi, } & \text { 10(2), }\end{array}$ doi:https://doi.org/10.21831/jpv.v10i2.30594

*Corresponding Author: Aprian Firmansyah aprian.smk@gmail.com

Department of Technology and Vocational Education, Graduate School, Universitas Negeri Yogyakarta

Jl. Colombo No. 1, Karangmalang, Depok, Sleman, Yogyakarta 55281, Indonesia 


\section{INTRODUCTION}

Education is everyone's need to guarantee a better life. Therefore, the state is obliged to facilitate every citizen without exception to get the opportunity to enjoy equal education service. This is written in article 31, paragraph 1 of Constitution 1945 which states that every citizen has the right to get education.

The quality improvement of education in Indonesia is included in the Government Regulation No. 19 of 2005 on the National Standard of Education which is the minimum criteria. The components of national standard of education consists of the standards of (1) graduate competence, (2) content, (3) teachers and school officials, (4) processes, (5) facilities and infrastructures, (6) financing, (7) management, and (8) assessment. This regulation indicates that vocational high school (VHS) is expected to produce quality graduates competitive and competent at their fields, so they can be employed in business and industrial sectors, where the local government also plays an important role in managing vocational education in accordance with regional autonomy which emphasizes the development of vocational education providers of VHS and vocational madrasah aliyah.

However, the real condition in the field is contradictory; VHS as the producer of skilled labour does not show the optimal employability of its graduates. This can be seen in the total workforce of 131.01 million in August 2018, an increase of 2.95 million compared to that in August 2017. In line with this, Labour Force Participation Rate (LFPR) also increased by $0.59 \%$. At the end of 2019, the number of the unemployed decreased by 40.000, in line with the TPT decrease of $5.34 \%$ in August 2018. Viewed from the level of education, the TPT of VHS was dominated by the other education levels, by $11.24 \%$. This phenomenon shows that vocational high school (VHS) expected to bridge the link and match is in fact cannot meet the expectation. The high unemployment of VHS graduates also shows that the relevance level of VHS education to their lives needs improvement. On the other hand, the graduates' unemployment is due to the fact that most VHS graduates in Indonesia are unable not only to adapt themselves to the development of science and technology but also to develop themselves and their careers in their workplace (Department of National Education, 2004, p. 1). This indicates that employability skills play an important role in workplace, so that every VHS graduate has to produce productive work.

Basically, employability skills are the skills which play an important role in doing a job effectively in the workplace with various competencies and knowledge that must be possessed to ensure that a person has the ability that matches the needs of his job (Chaita, 2017). They are basic skills that must be possessed by every worker in order to get, maintain, and do their work well and efficiently. They consist of two categories: hard skill and soft skill (Omar et al., 2012).

Hard skills are the skills in a field in the form of more technical abilities, which in this case tend to be the ability to create, repair, arrange, and form something. Hard skills are also known as competency-based knowledge (Dahlan, 2009). Therefore, they are more related to one's abilities acquired through learning and training related to expertise competence in certain fields in a certain period and duration, after undergoing which one is considered competent proven by a certificate in a certain expertise. Dell'Aquila et al. (2017, p. 1) write that the term soft skills or "people skill" is the attribute or a list of personality traits which can optimize and improve one's interaction with others, can be used every day by most people with different levels of existence, and in general, are considered as the combination of the competence in how one knows and manages oneself and his relationship with others. Soft skills refer to a set of competencies, skills, behaviours, attitudes, and qualities on an individual which enable him to make good relationship effectively with others, navigate his environment, work well, and achieve goals in life (Lippman et al., 2015, p. 11), where soft skills are one's skills in having relationship with other people (interpersonal skills) and the skills in managing himself (intrapersonal skills) that can develop to work maximally (Panuju, 2018, p. 58).

Most corporate owners nowadays look for employees competent in technical skill only but they need those who have additional skills in the form of soft skills such as communication skill, discipline, interpersonal skill, teamwork ability, problem solving ability, technological skill, continual learning skill, and positive work ethics to improve productivity and competitiveness (Esa et al., 2014). It shows that soft skills play a key role in determining the quality needed by business and industrial sectors. 
The need for and role of soft skills really determine one's success in business and industrial sectors. The research by Neff and Citrin (2010) found that $80 \%$ of one's career is determined by soft skills and $20 \%$ by hardskills. Widarto et al. (2012) on the analysis of the needs of business and industrial sectors show that the aspects of soft skills such as the motivation, personality and leadership of employees are very dominant requirements which are very important in business and indusrial sectors. Therefore, it can be concluded that soft skills become the main aspect or ability needed by employers, and jobseekers should consider this when starting their careers.

Developing soft skills in VHS education has to be based on real life, higher order thinking, the students' applicative activities, problem-based learning, authentic instruction, relevance-based teaching, project-based learning, service-based learning, and comparative learning (Johnson et al., 2008). In addition, soft skills play a very important role in VHS education beside hard skills. Soft skills become important parts of students' competence to be successful in their lives (Directorate General of Higher Education, 2008, p. 3), because they are related to work performance and career development of how to manage their interaction and emotion to interact effectively in their workplace (Dell'Aquila et al., 2017, p. 7). In other words, in soft skills, there are job character as the complementary competence which students must have, which can facilitate them to be effective and successful (Bhatnagar \& Bhatnagar, 2012, p. 6), particularly for vocational schools, which is very important to be given to their students as the provision for them to involve in business and industrial sectors which emphasize the mastery of soft skills.

Hendricksen (2012, p. 2) mentions there are 12 soft skills needed by the world of work, all of which are classified into three areas: relationship skills (leadership, politics, gracious behavior, communications, negotiations); personal skills (context switching, transparency, passion); and business skills (pragmatism, vision, business knowledge, and innovation). Helena and Thomas (2016) point out that there are 20 soft skills which are most preferred by recruiters of employees and expected from every jobseekers at the recruitment processes. The polling result of five companies of the IDCZ (Industrial Depelopment Corporation of Zimbabwe) group shows that the 10 soft skills expected from school graduates are the skills in critical thinking, morality, team work, ethics, selfcontrol, communication, integrity and professionalism, belief, self-confidence, and work culture understanding. The summary of the 20 soft skills which become the consideration of competence in the process of recruiting employees is shown in Table 1.

Table 1. The Atributes of Soft Skills Needed in Employee Recruitment

\begin{tabular}{clc}
\hline No & \multicolumn{1}{c}{ Attribute } & \% of Respondents \\
\hline 1 & Problem-solving skills & $82.9 \%$ \\
2 & Ability to work in team & $82.9 \%$ \\
3 & Communication skills (written) & $80.3 \%$ \\
4 & Leadership & $72.6 \%$ \\
5 & Strong work ethic & $68.4 \%$ \\
6 & Analytical skills & $67.5 \%$ \\
7 & Communication skills (verbal) & $67.5 \%$ \\
8 & Initiative & $67.5 \%$ \\
9 & Detail-oriented & $64.1 \%$ \\
10 & Flexibility & $60.7 \%$ \\
11 & Technical skills & $59.8 \%$ \\
12 & Interpersonal skills (relates well to others) & $54.7 \%$ \\
13 & Computer skills & $48.7 \%$ \\
14 & Organiziational ability & $48.7 \%$ \\
15 & Strategtc planning skills & $39.3 \%$ \\
16 & Creativity & $29.1 \%$ \\
17 & Friendly & $27.4 \%$ \\
18 & Tactfulness & $22.2 \%$ \\
19 & Entrepreneurial skills & $19.7 \%$ \\
20 & Fluency in a foreign language & $4.3 \%$ \\
\hline
\end{tabular}

(Source: National Association of Colleges and Employers, 2018) 
Based on Table 1, the field of education should realize the needs for the change in the VHS graduate quality which has so far been oriented to hard skills. It is time to include the development of the soft skills most needed by business and industrial sectors. This is due to the fact that school graduates are expected not only expert academically but also successful in soft skills in order to be able to compete in the world of work (Hinchliffe \& Jolly, 2011). The components of soft skills must be implemented in all school subjects, each of which has to adapt to and emphasize soft skills aspects (Adisusilo, 2012, p. 72).

Soft skills-oriented teaching needs strategies and careful planning from teachers so that the attributes of soft skills in the subjects are implemented optimally. Instructional planning involves the development of systematically organized strategies for teaching, so that teachers must be able to determine everything and technique to be taught before they do it (Santrock, 2014). The instructional planning made by teachers is designed in the form of a syllabus and lesson plans. A syllabus is the reference for preparing teaching framework for every teaching material while lesson plans are developed from the syllabus to direct the students' learning activities in an effort to achieve basic competence (Ministry of Education and Culture, 2016).

Judiani (2010) explains that developing soft skills values in the syllabus is done through: (1) analysing the standard of competence (SoC) dan basic competence (BC) in the content standard (CS) to determine that the soft skills value stated has been included in it; (2) showing the relationship between SC and BC with scores and indicators in order to determine the value to develop; (3) including the soft skills values in the syllabus; (4) including the values included in the syllabus in the lesson plans; (5) developing the processes of student active learning instruction which enables students to have opportunities to internalize values and show them in suitable behaviours; and (6) giving assistance to the students who have difficulties internalizing values and who want to show them in their behaviours. Vocational education refers to the program managed to train and improve employability skills with skills, attitudes, and knowledge so that the students are able to adapt themselves to the world of work (Sudira, 2016, p. 8). In this case, vocational education provides students not only with knowledge but also with employability skill in certain expertise.

One of the expertise programs needed by industries nowadays is the automotive engineering expertise program. The graduates of this program have a big chance to be employed in industrial sectors, because in Indonesia, many local and foreign companies and industries are engaged in transportation, so that almost all industries in Indonesia require the graduates of the automotive engineering expertise program. The teaching activities in this program are classified into three kinds of teaching: (1) theory teaching, (2) practicum teaching, and (3) practice teaching. Both practice teaching and practicum teaching are the application of the theories the students have learned. Viewed from the emphasis, there is a difference between theory teaching and practice teaching. Technical theory teaching puts more emphasis on cognitive training, while practice teaching puts more emphasis on psychomotor training, although both teachings are mutually related and supporting (Kartowagiran, 2018).

The result of the interviews done in one of the vocational high schools in West Lombok, whose resource person is the principal of VHS 2 Kuripan, shows that the implementation of soft skills has constraints with the subjects in the classroom and also practicum in workshop, but it is still tried to run in the subject taught in the classroom because soft skills are very important to teach to students in school. Besides, the result of the interview with the principal of VHS 1 Gunungsari shows that the implementation of soft skills in teaching is still difficult to do because many teachers do not quite understand about soft skills, and soft skills for them are character education which is taught in theoretical subjects.

Furthermore, the observation conducted in the implementation of practice teaching at the automotive workshop of the expertise of automotive light vehicle technology is not quite optimal, so it can be said that: (1) the lab, equipment and environment of the practicum workshop is not very clean, the condition of practice teaching is not conducive, and there is a lack of supporting equipment such as practicum tables - all of which are the problems found - so that the students have to work on the floor or outside the workshop, the practicum equipment is not well kept in the workshop, and in one of the schools the practicum workshop is also used for theoretical teaching due to the lack of classrooms; (2) students are not very enthusiastic about doing practicum in the 
workshop; many students do not come on time and prefer to play truant when there is a workshop activity. This can be seen in the students' attendance which shows less than $20 \%$ of them come on time, while the rest come late, or in the presence list of grade XII students which shows: leave permission 21 times, sick leave 25 times, absence 192 times, truancy 2 times, coming late 22 times, and the list of students' problems shows that many students seldom attend classes, they play their mobile phone during the lesson, and they often play truant; (3) there is a lack of facilities that encourage students to think creatively.

The problems such as the abovementioned can of course cause VHS graduates' competence quality which is not productive. Based on this problem and the growing importance of the role of soft skills, there needs to be a study on the implementation of soft skills in the automotive workshop practicum at VHS's in West Lombok Regency.

In addition, there has so far been no research on the implementation of soft skills in the teaching of automotive workshop practicum at state VHS's in West Lombok Regency. Therefore, the result of this research can be the information and guide for schools in the implementation of soft skills in the workshop practicum at the department of automotive light vehicle technology of state VHS is West Lombok Regency, West Nusa Tenggara Province.

\section{RESEARCH METHOD}

This research is a quantitative descriptive study applying the quantitative approach, in which the research object is the implementation of soft skill in the students doing practicum at the automotive light vehicle technology VHS's in West Lombok Regency. The research population is all state vocational high schools (SVHS) in West Lombok Regency which have the automotive light vehicle expertise program. Based on the data from the Branch Office of Education, 10 state vocational high schools in West Lombok Regency, Nusa Tenggara Barat Province run the automotive light vehicle expertise program.

Table 2. School Population

\begin{tabular}{llr}
\hline No & \multicolumn{1}{c}{ Schools } & Address \\
\hline 1 & SVHS 1 Lingsar & Batu kumbung, Lingsar, West Lombok Regency, Nusa Tenggara Barat \\
2 & SVHS 1 Gunungsari & Jln. Raya Sesele, Gunungsari, West Lombok Regency, Nusa Tenggara Barat \\
3 & SVHS 2 Lingsar & Dasan Gria, Lingsar, West Lombok Regency, Nusa Tenggara Barat \\
4 & SVHS 2 Kuripan & Jln. Tgh. Ibrahim A.H., Kuripan Utara, West Lombok Regency, Nusa Tenggara Barat \\
5 & SVHS 1 Narmada & Jl. Raya Mantang, Peresak, Narmada, West Lombok Regency, Nusa Tenggara Barat \\
6 & SVHS 1 Kuripan & Jln. Tgh Abdul Hafiz Kediri, West Lombok Regency, Nusa Tenggara Barat \\
7 & SVHS 1 Lembar & Jln. Gatot Subroto, Lembar, West Lombok Regency, Nusa Tenggara Barat \\
8 & SVHS 1 Sekotong & Jln. Sekotong, West Lombok Regency, Nusa Tenggara Barat \\
9 & SVHS 1 Tanjung & Jln. Karang Sobar, Tanjung, West Lombok Regency, Nusa Tenggara Barat \\
10 & SVHS 2 Sekotong & Jln. Sekotong, West Lombok Regency, Nusa Tenggara Barat \\
\hline
\end{tabular}

Table 2 shows the school sample, established using the purposive sampling technique. This is based on the consideration that the sample schools have automotive expertise program with the expertise competence of automotive light vehicle technology. Another reason for this is the limitation of time, fund, human resources, and permission from the schools. Thus, this research was conducted only in four schools, each of which was represented by one class, year 12 class. The number of the students in the sample schools, as the respondents in this research, is presented in Table 3.

Table 3. School Population

\begin{tabular}{lll}
\hline No & Schools & Respondents \\
\hline 1 & SVHS 1 Lingsar & 27 Respondents \\
2 & SVHS 1 Gunungsari & 16 Respondents \\
3 & SVHS 2 Lingsar & 16 Respondents \\
4 & SVHS 2 Kuripan & 25 Respondents \\
\hline
\end{tabular}

(Source:primary data, 2019) 
In this research, the data were in the form of the description of the implementation of soft skills in workshop practicum of light vehicle technology at state vocational high schools. The data were collected by using a questionnaire and through observation, and the supporting data were collected through interviews and documentation. The following are the steps of the data collection and analysis: (1) collecting data from respondents, (2) describing the data collected, and (3) presenting the data visually.

The data on the readiness of soft skills was viewed from the readiness of the students and review of the lesson plans. In addition, the data on the level of soft skills competence were collected using a questionnaire with five main indicators, namely: (1) discipline, (2) responsibility, (3) collaboration, (4) creative thinking, and (5) communication ability.

\section{RESULTS AND DISCUSSION}

\section{Findings}

The result of the analysis of the data on the soft skill competence level of the students of automotive light vehicle technology in each vocational high school in West Lombok Regency is presented in Table 4. The total mean score of student condition is 28.13 with the total standard of deviation (SD) of 3.18. Table 4 explains that there are 31 students $(36.9 \%)$ having a condition that is in a very good category, 39 students $(46.43 \%$ ) having a condition in a good category, 13 students (15.48\%) having a condition that is included in a sufficient category, one student (1.19\%) has a condition included in a poor category, and none of the students has a condition included in a very poor category.

Table 4. Result of Analysis of Student Condition Component

\begin{tabular}{|c|c|c|c|}
\hline Interval & Criteria & Total & Percentage \\
\hline$X>29.25$ & Very good & 31 & $36.90 \%$ \\
\hline $24.75<X \leq 29.25$ & Good & 39 & $46.43 \%$ \\
\hline $20.25<X \leq 24.75$ & Sufficient & 13 & $15.48 \%$ \\
\hline $15.75<X \leq 20.25$ & Poor & 1 & $1.19 \%$ \\
\hline$X \leq 15.75$ & Very poor & 0 & $0.00 \%$ \\
\hline \multicolumn{2}{|c|}{ Total } & 12 & $100.00 \%$ \\
\hline
\end{tabular}

Table 5. Readiness and Activeness Components

\begin{tabular}{ccc}
\hline Category & \multicolumn{2}{c}{ Percentage } \\
\cline { 2 - 3 } & Readiness & Activeness \\
\hline Very good & $33.33 \%$ & $39.29 \%$ \\
Good & $38.10 \%$ & $41.67 \%$ \\
Sufficient & $21.43 \%$ & $16.67 \%$ \\
Poor & $5.95 \%$ & $2.38 \%$ \\
Very poor & $1.19 \%$ & $0.00 \%$ \\
Total & $\mathbf{1 0 0 \%}$ & $\mathbf{1 0 0 \%}$ \\
\hline
\end{tabular}

Table 5 shows that the percentage of students with learning readiness is $33.33 \%$ in a very good criterion, and $38.10 \%$ in a good criterion. This means that the total percentage of students with learning readiness in very good and good criteria is $71.43 \%$. On the contraty, the percentage of students with learning readiness in sufficient, poor, and very poor criteria is $28.57 \%$. Therefore, it can be said that the total average of the students is in a good criterion of readiness. Meanwhile, in terms of students' activeness, $39.29 \%$ are in a very good criterion, and $41.67 \%$ in a good criterion. Therefore, the total percentage of the students in the very good and good activeness criteria is $80.96 \%$. On the other hand, the total percentage of the students in the sufficient, poor, and very poor activeness criteria is $19.04 \%$. Therefore, it can be said that the total average related to student' activeness is in a good criterion. 
Table 6. Result of Analysis of Lesson Plan Condition

\begin{tabular}{|c|c|c|c|}
\hline Interval & Criteria & Total & Percentage \\
\hline$X>65$ & Very good & 1 & $8.33 \%$ \\
\hline $55<X \leq 65$ & Good & 7 & $58.33 \%$ \\
\hline $45<X \leq 55$ & Sufficient & 3 & $25.00 \%$ \\
\hline $35<X \leq 45$ & Poor & 1 & $8.33 \%$ \\
\hline$X \leq 35$ & Very poor & 0 & $0.00 \%$ \\
\hline \multicolumn{2}{|r|}{ Total } & 12 & $100.00 \%$ \\
\hline
\end{tabular}

The total mean score of lesson plan condition is 58.73 with the SD of 8.57. Table 6 shows that the percentage of lesson plans in a very good criterion is $8.33 \%$, in a good criterion is $58.33 \%$, and in a sufficient criterion is $25.00 \%$. Furthermore, the percentage of lesson plans in a poor criterion is $8.33 \%$, and in a very poor criterion is $0 \%$. At this stage of analysis, the description of the result is viewed from students' soft skill competence level through a questionnaire. A description of the students' soft skill is presented in Table 7.

Table 7. Analysis of the Soft Skill Competence Level of Students of VHS's in West Lombok Regency

\begin{tabular}{|c|c|c|c|}
\hline Interval & Category & Total & Percentage \\
\hline$X>133.25$ & Very good & 14 & $17 \%$ \\
\hline $112.75<X \leq 13.25$ & Good & 41 & $49 \%$ \\
\hline $92.25<X \leq 112.75$ & Sufficient & 24 & $29 \%$ \\
\hline $71.75<X \leq 92.25$ & Poor & 5 & $6 \%$ \\
\hline$X \leq 71.75$ & Very poor & 0 & $0 \%$ \\
\hline \multicolumn{2}{|c|}{ Total } & 84 & $100 \%$ \\
\hline
\end{tabular}

The total mean score of students' soft skill competence level is 118.76 with the SD of 15.34. Table 7 shows that the percentage of students whose soft skill competence is in a very good category is $17 \%$, those whose soft skill competence is in a good category is $49 \%$, and those whose soft skill competence is in a sufficient category is $24 \%$. Besides, students whose soft skill competence is in a poor category is $6 \%$, and none has soft skill competence in a very poor category.

Table 8. Soft Skills Competence Level of Students of LVT VHS 1 Lingsar

\begin{tabular}{|c|c|c|c|}
\hline Interval & Criteria & Total & Percentage \\
\hline$X>133.25$ & Very good & 6 & $22 \%$ \\
\hline $112.75<X \leq 133.25$ & Good & 15 & $56 \%$ \\
\hline $92.25<\mathrm{X} \leq 112.75$ & Sufficient & 6 & $22 \%$ \\
\hline $71.75<X \leq 92.25$ & Poor & 0 & $0 \%$ \\
\hline $\mathrm{X} \leq 71.75$ & Very poor & 0 & $0 \%$ \\
\hline \multicolumn{2}{|c|}{ Total } & 27 & $100 \%$ \\
\hline
\end{tabular}

Table 8 shows the soft skill competence level of the students of SVHS 1 Lingsar, where six students (22\%) are in a very good criterion, 15 students (56\%) in a good criterion, six students $(22 \%)$ in a sufficient criterion, and none of the students is in neither poor nor very poor criteria.

Table 9. Soft Skills Competence Level of Students of LVT VHS 2 Kuripan

\begin{tabular}{|c|c|c|c|}
\hline Interval & Criteria & Total & Percentage \\
\hline$X>133.25$ & Very good & 6 & $24 \%$ \\
\hline $112.75<X \leq 133.25$ & Good & 10 & $40 \%$ \\
\hline $92.25<\mathrm{X} \leq 112.75$ & Sufficient & 6 & $24 \%$ \\
\hline $71.75<X \leq 92.25$ & Poor & 3 & $12 \%$ \\
\hline $\mathrm{X} \leq 71.75$ & Very poor & 0 & $0 \%$ \\
\hline \multicolumn{2}{|c|}{ Total } & 25 & $100 \%$ \\
\hline
\end{tabular}


Table 9 shows the soft skill competence level of the students of SVHS 2 Kuripan, where six students (24\%) are in a very good criterion, 10 students (40\%) in a good criterion, six students $(24 \%)$ in a sufficient criterion, three students $(12 \%)$ in a poor criterion, and none of the students is in a very poor criterion.

Table 10. Soft Skills Competence Level of Students of LVT VHS 1 Gunungsari

\begin{tabular}{|c|c|c|c|}
\hline Interval & Criteria & Total & Percentage \\
\hline$X>133.25$ & Very good & 0 & $0 \%$ \\
\hline $112.75<X \leq 133.25$ & Good & 11 & $69 \%$ \\
\hline $92.25<X \leq 112.75$ & Sufficient & 4 & $25 \%$ \\
\hline $71.75<X \leq 92.25$ & Poor & 1 & $6 \%$ \\
\hline $\mathrm{X} \leq 71.75$ & Very poor & 0 & $0 \%$ \\
\hline \multicolumn{2}{|c|}{ Total } & 16 & $100 \%$ \\
\hline
\end{tabular}

Table 10 shows the soft skill competence level of the students of SVHS 1 Gunungsari, where none of the students $(0 \%)$ is in a very good criterion, 11 students $(69 \%)$ in a good criterion, four students $(25 \%)$ in a sufficient criterion, one student (6\%) in a poor criterion, and none of the students is in a very poor criterion.

Table 11. Soft Skills Competence Level of Students of LVT VHS 2 Lingsar

\begin{tabular}{cccc}
\hline Interval & Criteria & Total & Percentage \\
\hline $\mathrm{X}>133.25$ & Very good & 2 & $13 \%$ \\
$112.75<\mathrm{X} \leq 133.25$ & Good & 5 & $31 \%$ \\
$92.25<\mathrm{X} \leq 112.75$ & Sufficient & 8 & $50 \%$ \\
$71.75<\mathrm{X} \leq 92.25$ & Poor & 1 & $6 \%$ \\
$\mathrm{X} \leq 71.75$ & Very poor & 0 & $0 \%$ \\
& & $\mathbf{1 6}$ & $\mathbf{1 0 0 \%}$ \\
\hline
\end{tabular}

Table 11 shows the soft skill competence level of the students of SVHS 2 Lingsar, where two students (13\%) are in a very good criterion, five students $(31 \%)$ in a good criterion, eight students $(50 \%)$ in a sufficient criterion, one student $(6 \%)$ in a poor criterion, and none of the students is in a very poor criterion.

Table 12. Soft Skills Competence Level of Students of LVT VHS in West Lombok Regency

\begin{tabular}{lccccc}
\hline \multirow{2}{*}{ Criteria } & \multicolumn{5}{c}{ Percentage } \\
\cline { 2 - 6 } & Discipline & Responsibility & Collaboration & Creative Thinking & Communication \\
\hline Very good & $54.76 \%$ & $48.81 \%$ & $13.10 \%$ & $7.14 \%$ & $8.33 \%$ \\
Good & $33.33 \%$ & $33.33 \%$ & $34.52 \%$ & $30.95 \%$ & $29.76 \%$ \\
Sufficient & $8.33 \%$ & $13.10 \%$ & $33.33 \%$ & $36.90 \%$ & $33.33 \%$ \\
Poor & $3.57 \%$ & $4.76 \%$ & $15.48 \%$ & $22.62 \%$ & $20.24 \%$ \\
Very poor & $0.00 \%$ & $0.00 \%$ & $3.57 \%$ & $2.38 \%$ & $8.33 \%$ \\
$\quad$ Total & $100 \%$ & $100 \%$ & $100 \%$ & $100 \%$ & $100 \%$ \\
\hline
\end{tabular}

Table 12 shows the condition of students' soft skills, where in terms of discipline, $54.76 \%$ of the students are in a very good criterion; in terms of responsibility, $48.81 \%$ are in a very good criterion; in terms of collaboration, $34.52 \%$ are in a good criterion; in terms of activeness, $36.9 \%$ are in sufficient criterion; and in terms of communication, $33.33 \%$ are in a sufficient criterion.

\section{Discussion}

Student condition in this research consists of student readiness and activeness in attending classes. The analysis result shows that $36.90 \%$ of the students have the condition in a very good category and $46.43 \%$ are in a good category. Viewed from each indicator - readiness and activeness, 
the description is as follows. The percentage of the students having readiness in a very good category is $33.33 \%$ and in a good category is $38.10 \%$. In contrast, the students having readiness in sufficient, poor, and very poor categories is $28.57 \%$. Thus, in average, the students have readiness in a good category. Viewed from students' activeness, $39.29 \%$ of them are in a very good category, and $41.67 \%$ in a good category. In contrast, $19.04 \%$ of them are in sufficient, poor, and very poor categories. Thus, in average, the students are in a good category in terms of activeness. The discrepancy of the field data with what was expected is due to some problems in the students, both in terms of their readiness and activeness in teaching-learning processes. In the readiness aspect, students still tend to be so doubtful about their ability to follow the practice lesson that make some of them tend to be quiet although there are learning materials that they do not understand, and furthermore, it made some students feel not very interested in participating in practical lesson. This is in line with the finding that students' level of readiness has impact on their activeness in learning automative engineering. In the aspect of activeness, some students are passive in communicating their opinions or ideas in responding to their teachers' questions. One of the factors causing the lack of student activeness intensity is teachers' unoptimal sensitivity in understanding students' characteristics, from the perspectives of cognitive ability, learning style, learning motivation, and attitudes.

Instructional planning is the activity of formulating the action to be implemented in teaching processes, which simultaneously becomes an important guide for teachers and students in the classroom. This means that instructional planning can facilitate teachers to identify whether the teaching components designed or developed has been implemented in the teaching-learning processes. In this research, the description of the achievement of the lesson plans made by the teachers was evaluated through document review. The result of the analysis shows that as a whole the lesson plans made by the teachers are in a good criterion, with the achievement percentage of $58.33 \%$. The problems related to lesson plans is that the indicators developed by the teachers are not in line with the aspect of attitudes measured. In addition, the choice of learning resources the teacher wrote in the lesson plans is not very suitable with the students' characteristics, and in the teaching scenario are found the teaching activities not suitable with the approach used. However, overall the percentage of the achievement of the lesson plans made by the teachers has been good. Therefore, it can be concluded that the condition of the lesson plans made by the teachers is in a good criterion despite some consideration. The consideration is that in making lesson plans, the teachers must pay attention to the parts related to indicator formulation, choice of learning resources, and teaching model.

Soft skills competence in this research refers to VHS students' soft skill achievement as an impact of the integration of soft skills in teaching. The students' observable soft skill attributes are five aspects, including discipline, responsibility, collaboration, creative thinking, and communication. From the five aspects are found the achievement percentage of $49 \%$, which means that overall the soft skill achievement of the students is in a good criterion. This achievement shows there is a problem or a lack related to students' soft skill achievement. As to the percentage of the students achieving soft skill competence, the percentage of the students achieving the attribute of discipline is $54.76 \%$ (very good category), that of those achieving the attribute of responsibility is $48.81 \%$ (very good category), that of those achieving the attribute of collaboration is $34.52 \%$ (good category), that of those achieving the attribute of creative thinking is $36.90 \%$ (sufficient category), and that of those achieving the attribute of communication is $33.33 \%$ (sufficient category).

Overall, the percentage of the students achieving each attribute is in very good and sufficient criteria. The problem found is in the attribute of collaboration, creative thinking, and communication. In the attribute of collaboration, the problem considered not optimal is related to students' involvement in discussions about the group problems, in the sufficient criterion, which means that the students show a passive attitude to conveying their ideas. This problem has impacts on the attribute of students' creative thinking. The problem with this attribute, which teachers have to pay attention to, is that the students are still lacking in thinking to produce ideas or opinions fast. In addition, another problem observed during the teaching process related to the attribute of creative thinking is that the students looked reluctant to ask questions when there was an unclear explanation from the teacher, which then spread to another problem in this attribute, where some students cannot practise the planned solution already made when they encountered constraints when machine practicum was in progress. The problem with the attribute of collaboration and creative thinking is considered in 
line with the problem with the attribute of communication. In other words, the students are not very active communicating well with both their teacher and peers. This is shown by the problem occurring in the attribute of communication, where the problem found is that the students were not selfconfident in expressing their ideas well in speaking and writing. These problems can be said to be the impact of the problems in the learning process, which have been described previously. The aspects of the level of students' soft skills when viewed separately from the level of soft skills of each SVHS in West Lombok Regency are described as follows. The analysis result of the percentage of students' soft skills competence level of LVE SVHS 1 Lingsar is in a good category with the percentage $56.00 \%$, while in LVE SVHS 2 Kuripan, they are in a good category with the percentage of $40.00 \%$, in LVE SVHS 1 Gunungsari, they are in a good category with the percentage of $69.00 \%$, and in LVE SVHS 2 Lingsar, they are a sufficient category with the percentage of $50.00 \%$.

Sutrisno (2016) conducted a study whose findings are as follows. (1) The collaboration between VHS and industries should include the needs of the curriculum adopted in VHS. The curriculum includes hard skills and soft skills, where the hard skills should consist of knowledge (25\%) and skill (35\%), while the soft skills consist of character (24\%) and physical condition (16\%). (2) The teaching of soft skills can be conducted through two models: integrated model (integrated with hard skills in teaching) and complementary model (the implementation is in the curricular education). The similarity of Sutrisno's research and this research is that both studies deal with the aspect of soft skills in the teaching in VHS by considering the skills needed in the world of work.

The result of this research shows that there is a problem or lack in the mastery of soft skills of the students. In the attributes of discipline and responsibility, the percentage of achievement in each trait is in a very good criterion, and thus it can be said that it has met the expectation. The problems that are found are in the attributes of collaboration, creative thinking, and communication, whose overall achievement percentage is still in a sufficient criterion.

\section{CONCLUSION}

Teachers need to pay more attention to the components that have been designed or developed in the lesson plans so that the teaching can be carried out systematically and schematically as planned. Planning the practice teaching still has to be improved, especially in teaching strategies that must be adapted to the conditions of the practicum workshop so that the teaching activity can be more productive. Teachers must pay attention to the attributes of students' soft skill, particularly the attributes of collaboration, creative thinking, and also communication. This improvement can be made by teachers by giving more stimuli in the teaching process so that students can explore opinions and ideas.

\section{REFERENCES}

Adisusilo, S. (2012). Pembelajaran nilai-nilai karakter: Konstruktivisme dan VCT sebagai inovasi pembelajaran afektif. Raja Grafindo Persada.

Bhatnagar, N., \& Bhatnagar, M. (2012). Effective communication and soft skills. Pearson.

Chaita, M. V. (2017). Developing graduate employability skills: Your pathway to employment. Universal.

Dahlan, D. (2009). Start young: Tips dan trik sukses di usia muda. PT Grasindo.

Dell'Aquila, E., Marocco, D., Ponticorvo, M., Di Ferdinando, A., Schembri, M., \& Miglino, O. (2017). Educational games for soft-skills training in digital environments. Springer.

Department of National Education. (2004). Pengembangan kurikulum sekolah menengah kejuruan. Department of National Education, Republic of Indonesia.

Directorate General of Higher Education. (2008). Pengembangan soft skills dalam proses pembelajaran di perguruan tinggi. Directorate General of Higher Education of the Republic of Indonesia. 
Esa, A., Selamat, A., Padil, S., \& Jamaludin, J. (2014). Applications of soft skills in engineering programme at polytechnic Malaysia. Procedia - Social and Behavioral Sciences, 140, 115120. https://doi.org/10.1016/j.sbspro.2014.04.395

Government Regulation No. 19 of 2005 on the National Standard of Education, (2005).

Helena, J., \& Thomas, B. (2016). An investigation into the soft skills that employers in Zimbabwe expect graduate jobseekers to possess: A study of five companies under the Industrial Development Corporation of Zimbabwe (Limited) Group. Global Journal of Human Resource Management, 4(2), 1-20. http://www.eajournals.org/wp-content/uploads/AnInvestigation-into-the-Soft-Skills-That-Employers-in-Zimbabawe-Expect-Graduate-Jobseek ers-to-Possess.pdf

Hendricksen, D. (2012). 12 Essential skills for software architects. Pearson Education.

Hinchliffe, G. W., \& Jolly, A. (2011). Graduate identity and employability. British Educational Research Journal, 37(4), 563-584. https://doi.org/10.1080/01411926.2010.482200

Johnson, D. W., Johnson, R. T., \& Holubec, E. J. (2008). Cooperation in the classroom (8th ed.). Interaction.

Judiani, S. (2010). Implementasi pendidikan karakter di sekolah dasar melalui penguatan pelaksanaan kurikulum. Jurnal Pendidikan Dan Kebudayaan, 16(9), 280-289. https://doi. org/10.24832/jpnk.v16i9.519

Kartowagiran, B. (2018). Optimalisasi uji tingkat kompetensi di SMK untuk meningkatkan soft skill lulusan. Jurnal Dinamika Vokasional Teknik Mesin, 3(2), 101-109. https://doi.org/ 10.21831/dinamika.v3i2.21406

Lippman, L. H., Ryberg, R., Carney, R., \& Moore, K. A. (2015). Key "soft skills" that foster youth workforce success: Toward a consensus across fields. Child Trends.

Ministry of Education and Culture. (2016). Revitalisasi pendidikan vokasi. Ministry of Education and Culture.

National Association of Colleges and Employers. (2018). Employers want to see these attributes on students' resumes. NACEweb.Org. https://www.naceweb.org/talent-acquisition/candidateselection/employers-want-to-see-these-attributes-on-students-resumes/

Neff, T. J., \& Citrin, J. M. (2010). Lesson from the top. Doubleddy Business.

Omar, M. K., Bakar, A. R., \& Rashid, A. M. (2012). Employability skill acquisition among Malaysian community college students. Journal of Social Sciences, 8(3), 472-478. https:// doi.org/10.3844/jssp.2012.472.478

Panuju, R. (2018). Pengantar studi (ilmu) komunikasi: Komunikasi sebagai kegiatan - komunikasi sebagai ilmu. Kencana.

Santrock, J. W. (2014). Educational psychology (5th ed.). McGraw-Hill Education.

Sudira, P. (2016). TVET abad XXI: Filosofi, teori, konsep, dan strategi pembelajaran vokasional. UNY Press.

Sutrisno, B. (2016). Profil model pembelajaran soft-skill pada SMK bidang Ekonomi di Surakarta (Kajian aspek apa; mengapa; dan bagaimana). Jurnal Pendidikan Ilmu Sosial, 26(2), 115135. https://doi.org/10.2317/jpis.v26i2.3354

Widarto, W., Pardjono, P., \& Widodo, N. (2012). Pengembangan model pembelajaran soft skills dan hard skills untuk siswa SMK. Jurnal Cakrawala Pendidikan, 31(3), 409-423. https://doi.org/10.21831/cp.v0i3.1139 